\title{
Design an intelligent system based on a computational cognitive model using attention network task
}

\author{
1. PhD Student of Cognitive Modeling, Institute for Cognitive Science Studies, Tehran, Iran \\ 2. Associate Professor of Physics, Amirkabir University of Technology, Tehran, Iran \\ 3. Associate Professor Psychology, Institute for Cognitive Science Studies, Tehran, Iran
}

Azadeh Haratiannezhadi ${ }^{1}$ (D), Saeed Setayeshi², Javad Hatami $^{3}$

Recieved: 16 Jul. 2019

Revised: 14 Nov. 2019

Accepted: 28 Nov. 2019

\section{Keywords}

Attention network task

Brain-computer interface (BCI)

Machine learning

Brain signals

\section{Corresponding author}

Azadeh Haratiannezhadi, PhD Student of Cognitive Modeling, Institute for Cognitive Science Studies, Tehran, Iran

Email: Azadeh.haratian@gmail.com

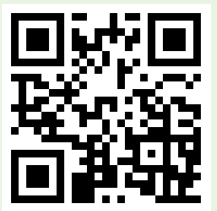

\section{Abstract}

Introduction: The attention is a gateway for learning and a limited resource. Attention cognitive model helps to perceive and use it efficiently. This research aimed to find an intelligent model for a different level of attention.

Methods: Developing a cognitive model based on the attention network task and brain signals. The model builds on machine learning techniques. The initial research population consists of 92 adult volunteers who completed the Depression Anxiety Stress Scales test (DASS-21). Based on the test results, 31 subjects selected and invited to take Attention Network test and during the test, brain signals were captured for this purpose, Brain-computer Interface (BCI) was used and a model constructed based on different levels which used subject's brain signal, reaction time and test result.

Results: Data were classified based on different machine learning methods such as Support Vector Machine (SVM), K-Nearest Neighbor (KNN), and Adaboost. The correct classification rate for these classifiers is 68,90 , and 87 percent.

Conclusion: The final model is selected based on the accuracy. So the KNN classifier has better generalization and it estimates test data better than other classifers. The desired Nero-cognitive model is based on the results and $\mathrm{KNN}$ classifiers are the best option for these types of cognitive models which is difficult to gather data and the dataset's size are small.

Citation: Haratiannezhadi A, Setayeshi S, Hatami J. Design an intelligent system based on a computational cognitive model using attention network task. Advances in Cognitive Sciences. 2020;22(1):81-92. 


\title{
طراحى يك ماشين هوشمند مبتنى بر مدلسازى شناختى با استفاده از تكليف شبكة توجه
}

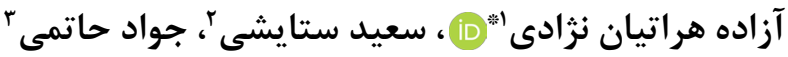

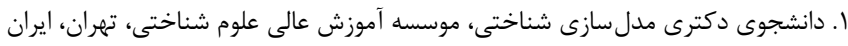

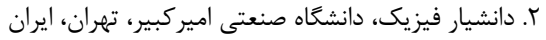

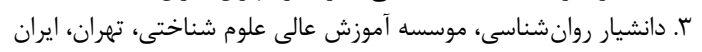

\begin{abstract}
ars
مقدمه: توجه دروازءٔ يادكيرى و يكى از منابع قابِ يردازش است كه مدلسازي شناختى آن به درى و استفاده بهتر از آن كمك مى كند. هدف از اين يزوهش ايجاد مدلى هوشمند با كارايى بسيار براى دستهبندى سطوح مختلف توجه بود. روش كار: ايجاد مدل شناختي توجه با استفاده از نتايج تكليف شبكؤ توجه و امواج مغزى انجام كرفت. به اين منظور، با استفاده از روشهاى مختلفِ يادكيري ماشين، به ايجاد مدلى از توجه يرداخته شد. در اين يُروهش، جامعهُ آمارى شامل كو فرد بزركسال داوطلب بود كه به صورت تصادفى انتخاب شده و يرسشنامه DASS-21 را براى انتخاب اوليه انجام دادند. سيس بر اساس نتايج، از آس نفر بيمارى كه افسردگى و اضطراب نداشتند و واجد شرايط بودند، براى مرحلئ نهايى دعوت به عمل آمد. در حين تكليفِ شبكهُ توجه، با استفاده از سيستم واسط كاربرى مغز، از شركت كنندكان سيحنال مغزى كرفته شد و مدلى از سطوح مختلف با استفاده از سيكنالهاى مختلف، زمان واكنش و درستى جواب شركت كننده ايجاد كرديد. يافته ها: دادهها با روشهاى دستهبندي يادَيري ماشينهاى مختلفى مانند ماشين بُردارهاى يشتيبان نزديكترين همسايكى (KNN) و آدابوست (Adaboost) بررسى شد و مدلى كه كمترين خطاى دستهبندى را داشت

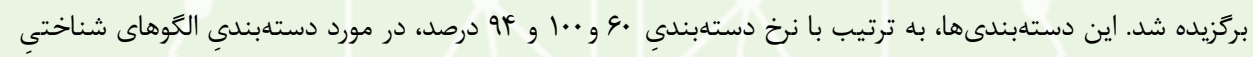
"توجها،، توانايىهاى مختلفى را براى اين مجموعه از دادها نشان داد. نتيجه گَيرى: بر اساس نتايج دقت دستهبندىها، مدل مناسب انتخاب شد و دستلبندى KNN از نظر تعميمهيذيرى و تخمين دادههاى آزمون دقت بهترى از بقيه مدل هاى انتخاب شده در اين يروهش را نشان داده است. براى اين نوع از مدلهاى شناختى كه در آن امكان جمع آوري حجم كمترى داده وجود دارد نيز مدل مناسب تلقى مىشود.
\end{abstract}

دريافت:

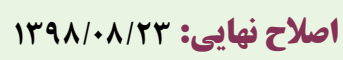

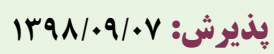

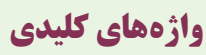
تكليف شبكؤ توجه سيستم واسط كاربرى مغز تونه يادكيرى ماشين سيخنال مغزى

نويسنله مسئول آزاده هراتيان نزادى، دانشجوى دمئول دكترى

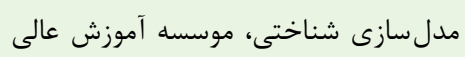

$$
\text { علوم شناختى، تهران، ايران }
$$

ايميل: Azadeh.haratian@gmail.com

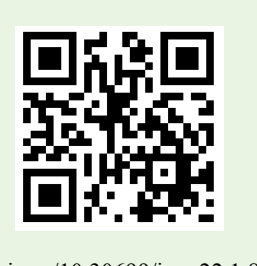

dol doi.org/10.30699/icss.22.1.8

مقلدمه

كه سيستم يردازشى ظرفيت اندكى دارد، مغز بايد ساز و كارهايى براى انتخاب اين اطلاعات داشته باشد. عملكردهاى اصلى توجه عبارتاند از: () يايدارى رفتارهاى مبتنى بر هدف و محافظت در برابر رويدادهاى

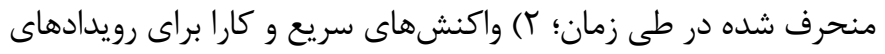
جديد. سامانه "اتوجه" بايد به اهداف شخصى مربوط باشد و اين سامانه
توجه نقش مهرمى در يادگيرى و عملكرد روزانهُ انسان دارد و در عين حال جزو حساسترين و يكى از مهمترين فرايندهاى شناختى است. توجه مستلزم انتخاب است. در واقع، توجه تعاملى موفق با محيط است و به عنوان دروازه شناختى عمل مى كند (1). به عبارت ديخر، هر زمانى كه محيطى كشف مىشود، اطلاعات زيادى جمع آورى مى گردد و از آنجا 
كاربرى مغز (Computer Interface Brain (BCI) براى ثبت EEG) استفاده شده است، زيرا برنامؤ تكليف شبكؤ توجه مبتنى بر وب نوشته

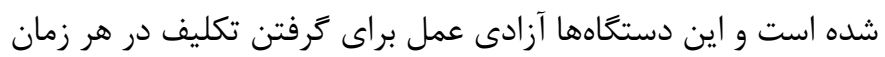
و مكانى را مى دهند. سيستم واسط كاربرى ابزارى است كه فعاليت الكتروفيزيولوزى يا نرخ

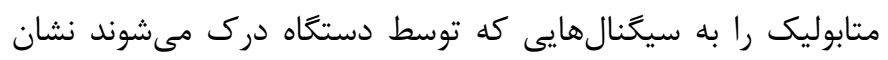

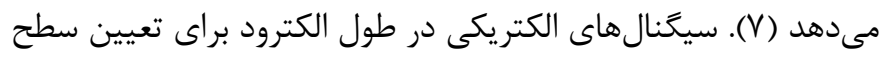

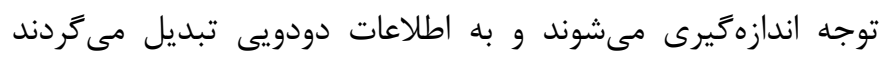

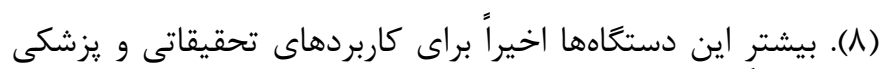

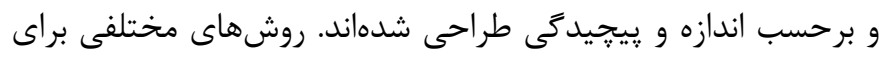

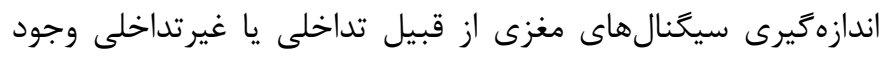

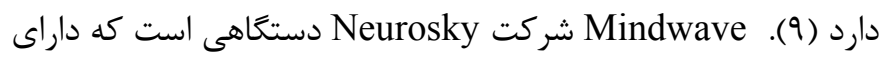

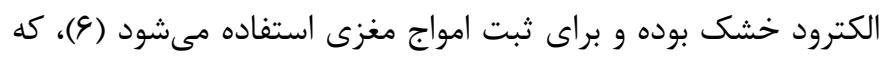

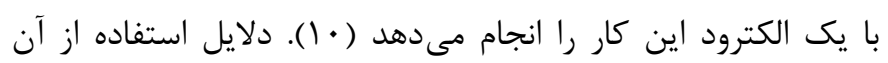

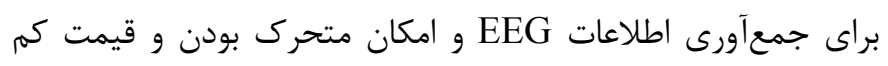
است. انتقال اطلاعات EEG از طريق بلوتوث است. باندهاى مختلفى را

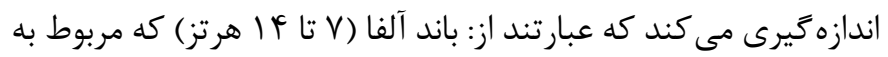

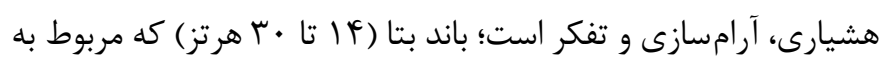

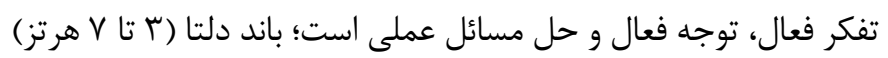

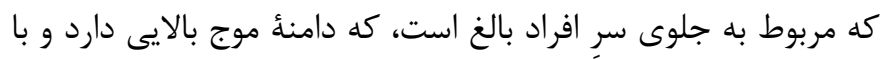

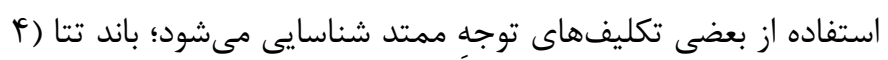

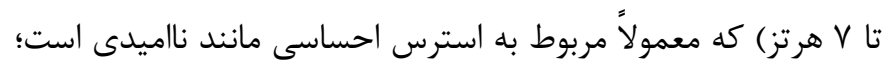

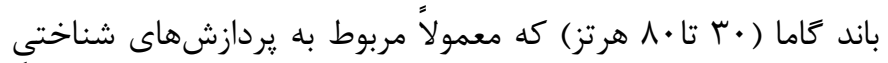

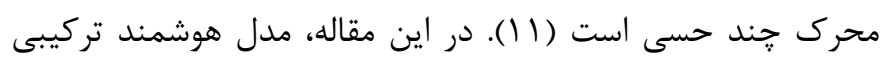

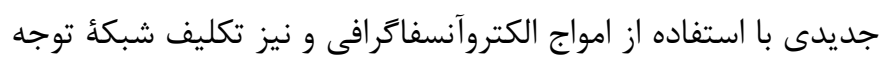

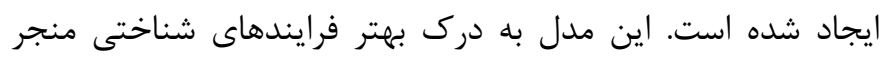
مىشود. در ادامه به بررسى يزوهشهاى مختلفى كه با همين دستخاه و براى تكليفهاى روانشناختى و مدلهاى يادكيرى ماشين انجام شده است يرداخته شد. خوابآلودگى يكى از مشكلات شناخته شده كاركران است، مخصوصاً

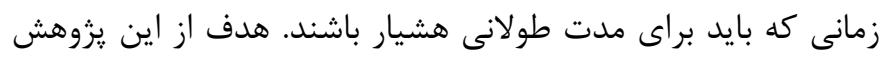

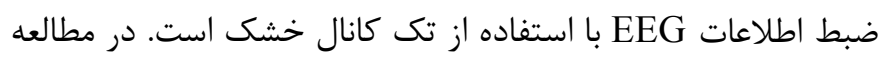
Schwartz Jones

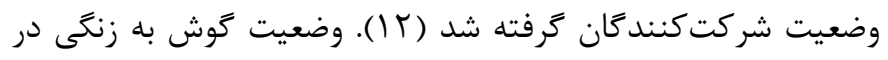

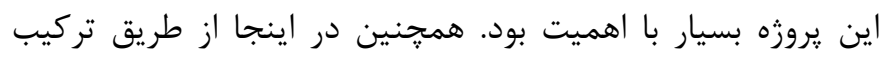
روشهاى علوم شناختى و روشهاى يردازش اطلاعات به بهبود تحليل و تفسير فرايندهاى شناختى مبتنى بر رنغ از طريق دستخاه
بر اساس تجارب قبلى كار در محيط است (Y). اين سامانه شناختى تنها

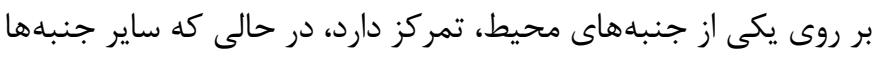

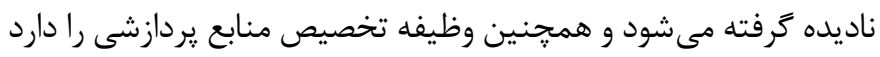

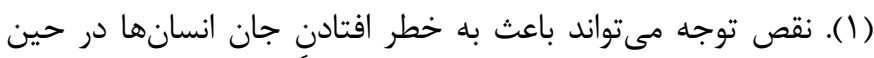

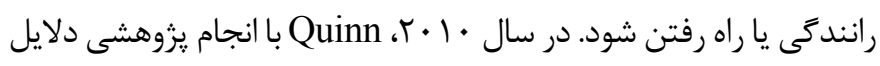

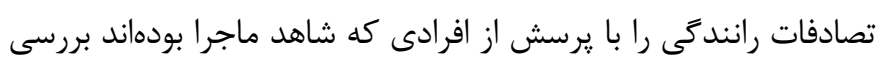

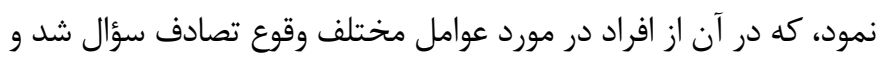

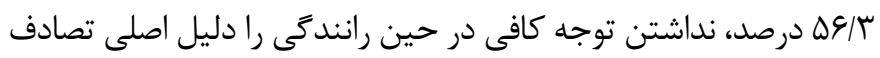

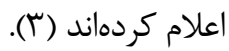

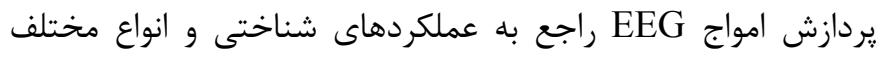

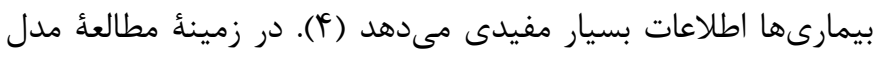

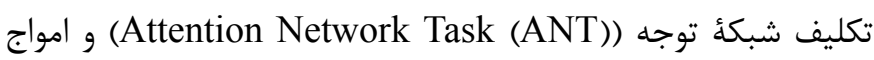
EEG

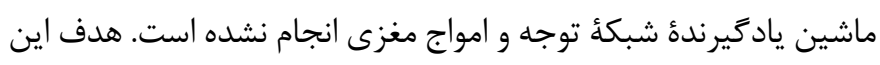
يزوهش تحقيق در همين زمينه و دستهبندى سطوح توجه با استفاده

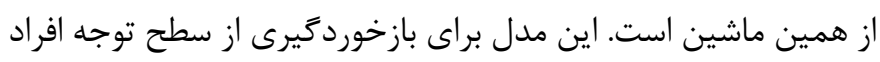

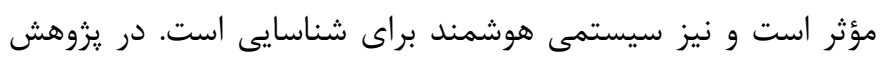

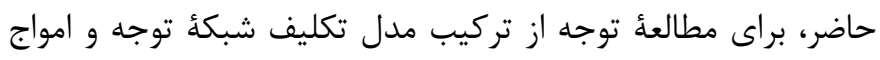

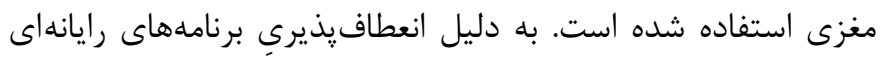

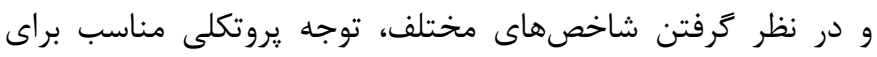

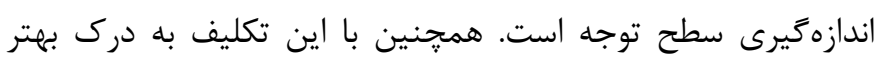

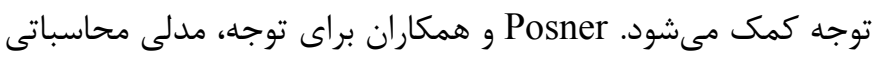

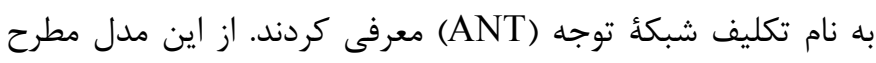

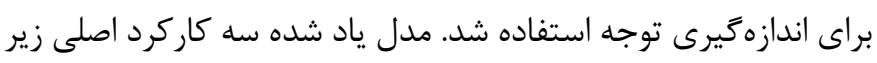

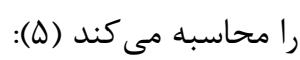
ا. قابليت يردازش سيخنال ها يا هشدارهايى با اولويت زياد

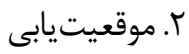

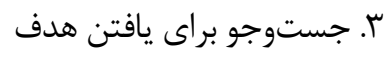
يكى ديكر از روش هاى اندازهخيرى توجه استفاده از امواج مغزى است.

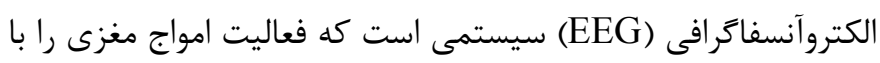

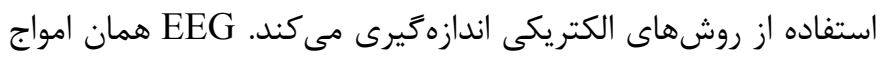

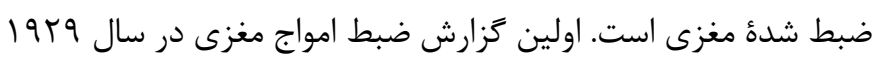

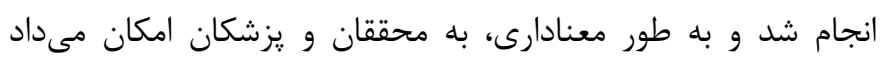

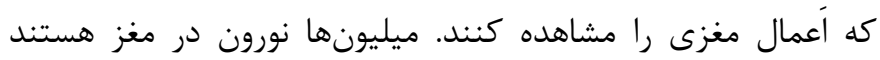

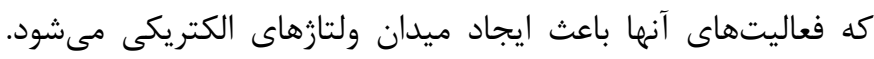

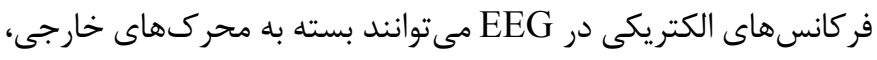

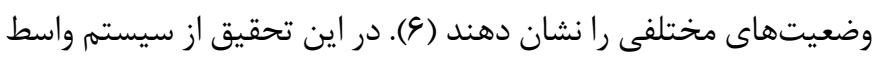


اين كار سه روش استفاده شد. اول به صورت مكانيزم كنترلى براى كنترل عناصر واسط كاربرى مانند منو يا دكمهها؛ دوم براى يافتن سطح تمركز كاربر به بخشى از صفحهٔ نمايشكر (براى اين منظور

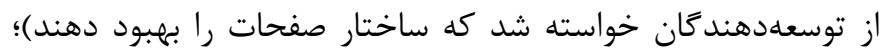

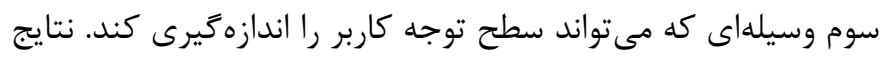
تحقيق ايجاد وبسايتى است كه به توجه كاربر حساس است. تمام

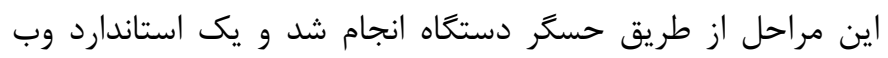

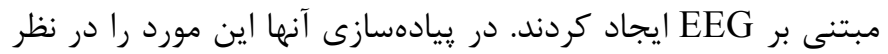
كرفتند كه آر بر يك آيتم بيش از يك ثانيه تمركز داشتند همجنان

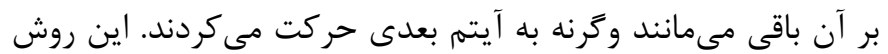
سومى است كه توجه مىتواند در جستجوى اينترنت (Browsing) استفاده شود. هدف ايجاد مروركرى است كه به توجه حساس باشد الدا

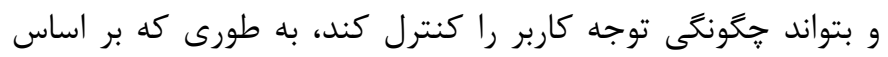

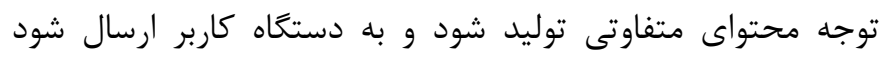

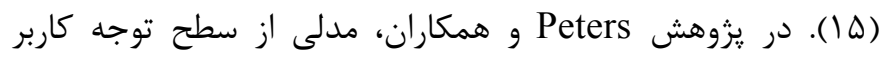

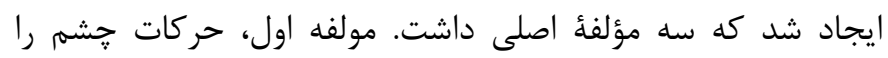

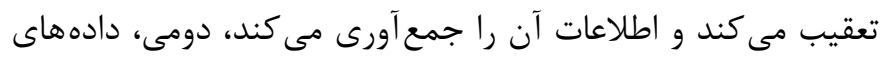
نوروفيزيولوزى است كه اطلاعات را با استفاده از دستخاه Neurosky كردآ ورى مى كند كه شامل سطح توجه و آرام سازى است. مولفه سوم، مدل تركيبى از دو مؤلفهُ قبلى است كه موقعيت مكانى، زمانى و درجه

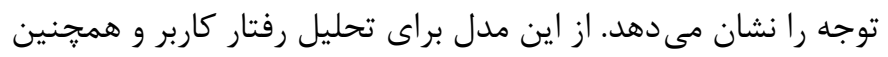
اطلاع به عامل (Agent) و مديريت تعاملات استفاده مى شود (ع) (1).

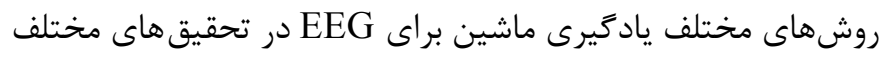

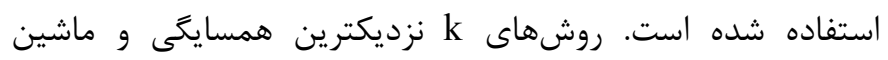
بردارهاى پشتيبان (Support Vector Machines (SVM)) براى ايجاد مدل و دستهبندى انواع احساسات استفاده شده است (IV).

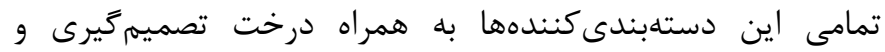
دستدبندى كنندهاى تركيبى استفاده شد. در مقاله Ghanbari و همكاران نيز از دستهبندى كننده مبتنى بر شبكهٔ عصبى مصنوعى

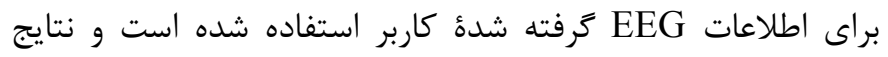

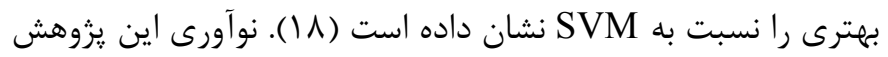
در مدلى با هوشمند عصبىشناختى توجه است و ايجاد مدلى كه هر النى

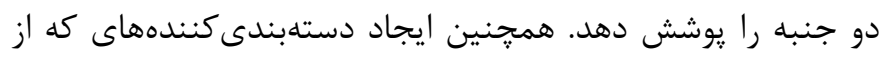

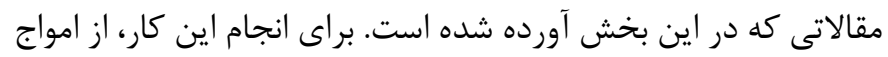

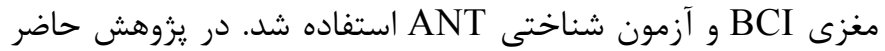
سعى شد كه مدلى هوشمند براى اندازهكيرى سطوح توجه ايجاد شود. كه در بخش بعد به تفصيل درباره آن توضيح داده شده است.
نيز يرداخته شد. براى انجام اين كار بايد اول بر اساس مقايسٔ نتايج سنتى روش تحليل شناختى (كيفى و كمى) به وسيلة تحليل

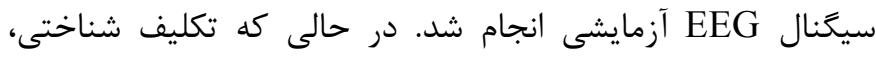

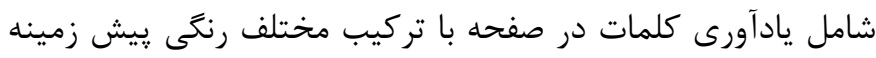

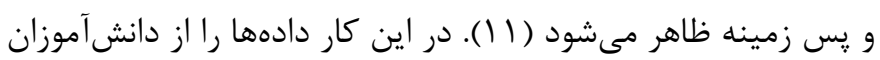

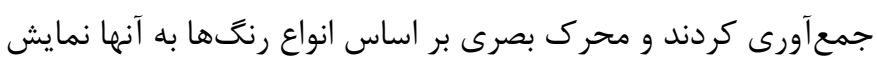

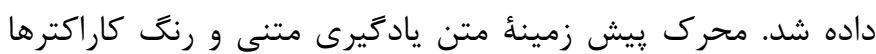

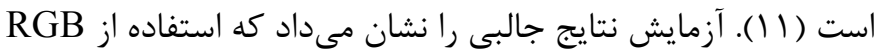
اصلى و رنغَهاى مكمل CMY است. براى كرفتن بازخورد خودآكاه و ناخودآكاه از كاربر، از EEG مبتنى بر BCI استفاده شد. در اين

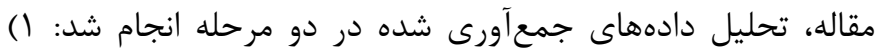

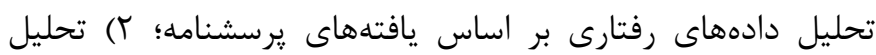
سيكنال EEG (1) (1). شناخت و خلاصهسازى فعاليتها، در افزايش آكاهى شخصى مؤثر

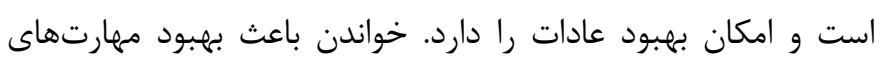

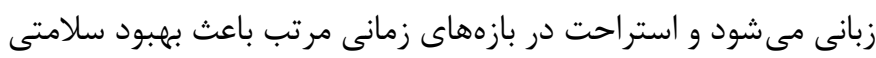
مىشود. شناخت اين فعاليتها و هدايت زمانى كه صرف مىشود به به كاربر امكان استراحت و خواندن كافى را مىدهد. در اين يزوهش از دستخاه Neurosky استفاده شد. اين دستخاه قابليت تشخيص فعاليتهاى مغزى كاربر را دارد و مدل يشنهادى، اقدام به با بازخورد

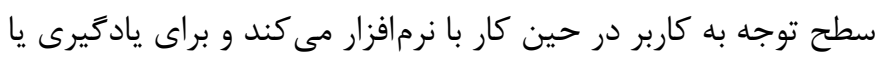

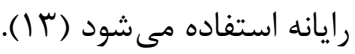

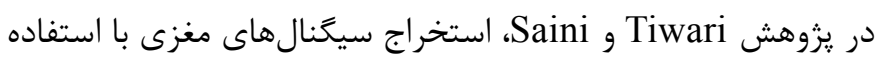
از روشهاى غيرتداخلى با واسط مغز و رايانه انجام شده است. اين وندين

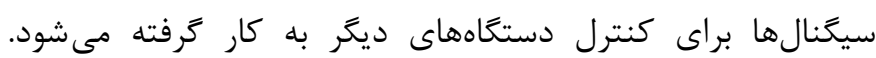

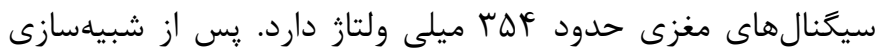

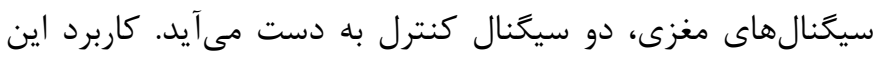
روش در حركت روبات است. مقادير توجه و آرامسازى انسان را براى كنترل روباتها استفاده مى كند. روبات با ميزان مشخصى از توجه

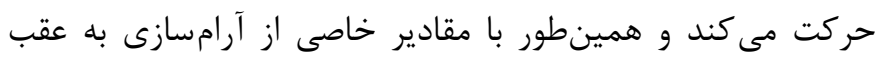

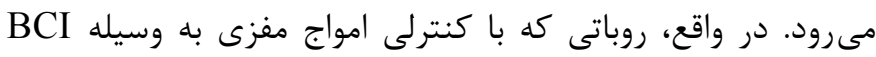

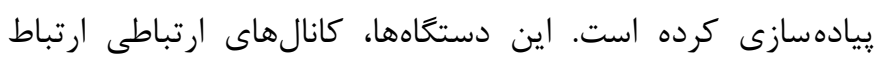

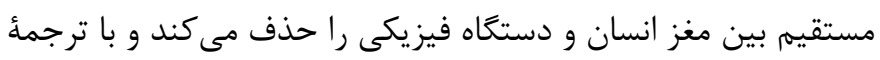

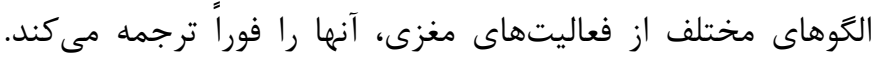

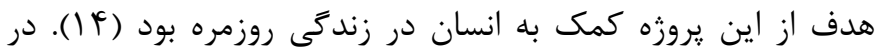

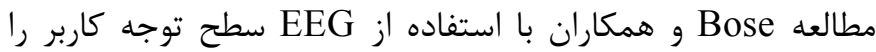
در حين بازديد از يك صفحه وب اندازهيرى كردند. براى انجام 
ارزيابى حالات عاطفه منفى در افسردگى، اضطراب و استرس است.

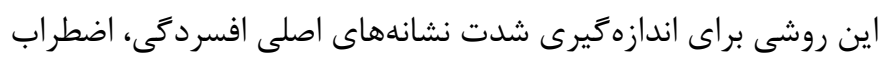

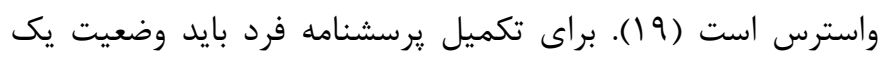

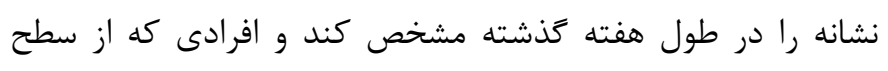

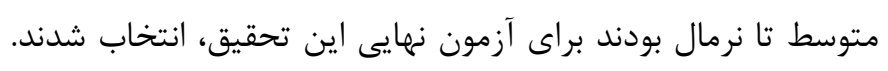

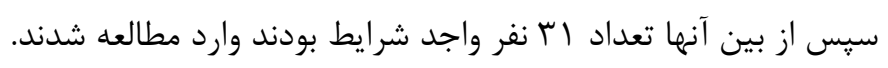

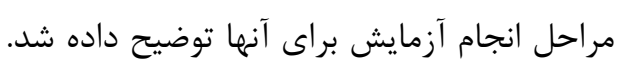

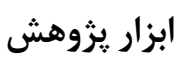
فرايند اجراى آزمون تحت وب انجام شد. آزمون در اتاقى ساكت كه

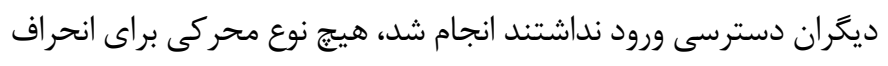

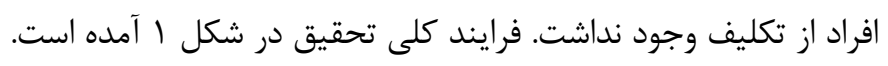

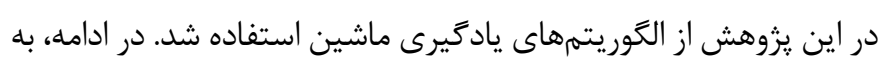
جزئيات بخشهاى مختلف يرداخته مى بـودي.
روش كار

با توجه به ماهيت يزوهش حاضر، تركيبى از روشهاى علوم شناختى

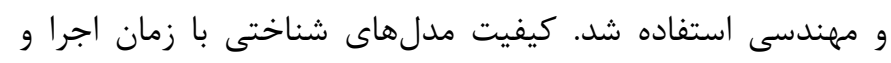

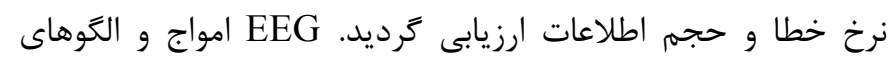

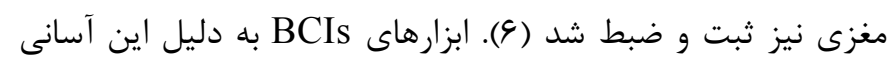

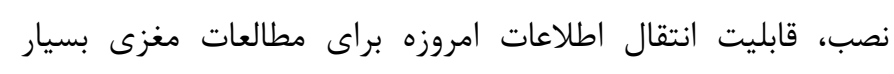

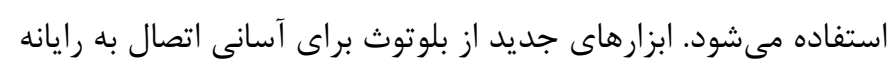

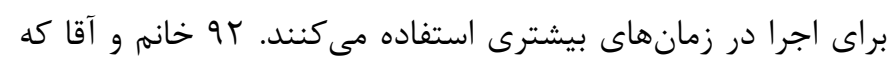

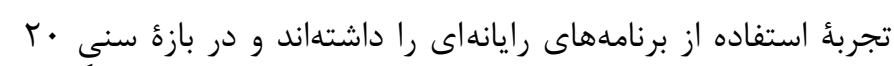

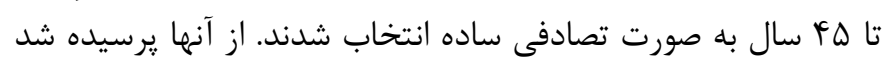

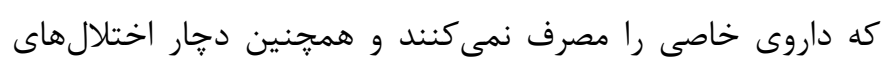

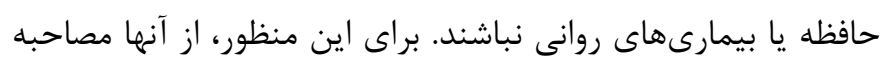
و يرسشنامه

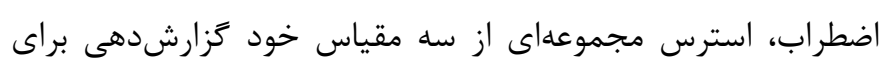

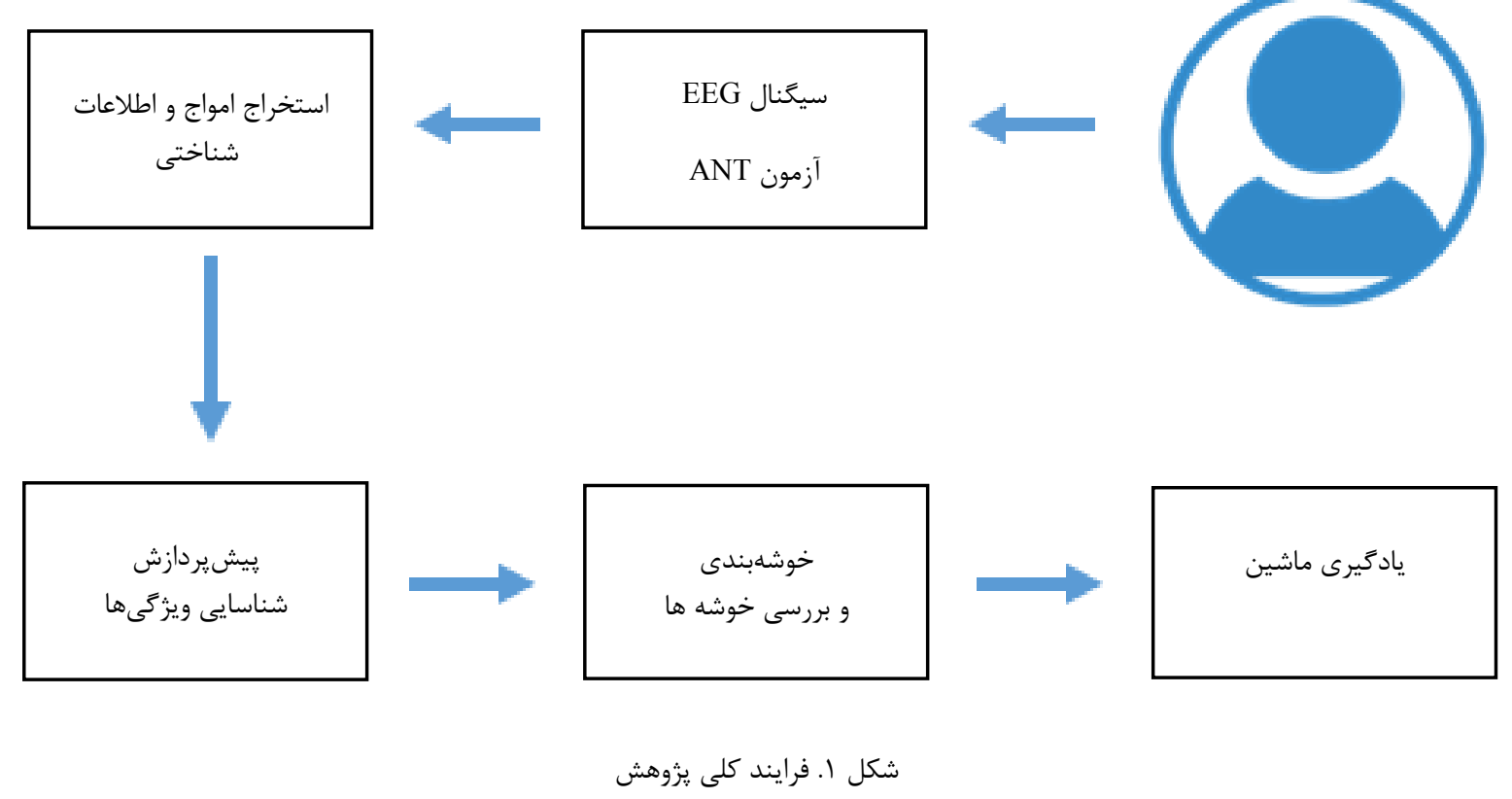

كه فلش جِ را شركت كننده در آزمون مشاهده كرد، كليد متناظر خِّ

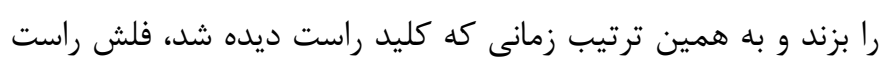

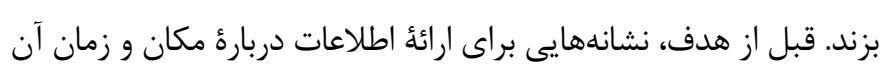

نمايش داده مىشود، مطابق شكل ب (I (Y).

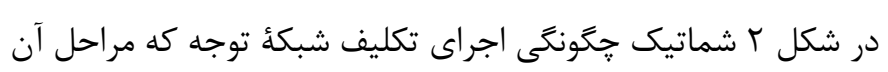

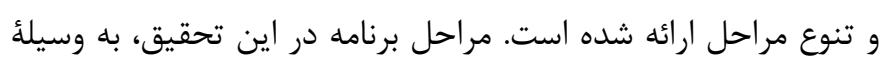

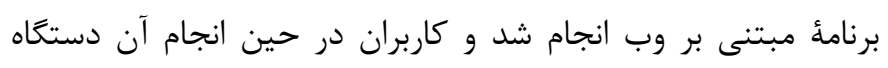
Neurosky
ا. ا. تكليف شبكئ توجه

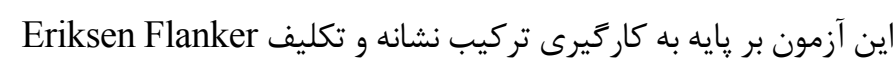

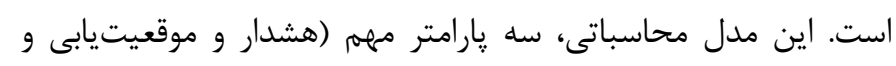

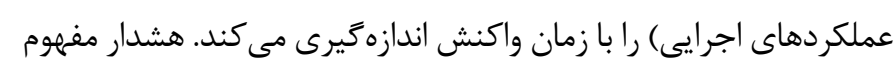

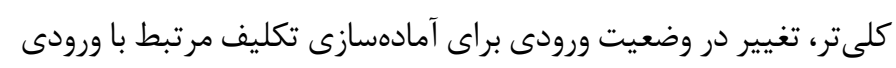
است. موقعيتيابى انتخاب اطلاعات از ورودى حسى است و و كنترل

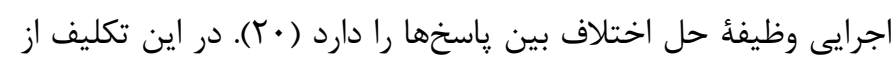

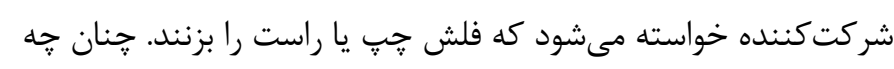




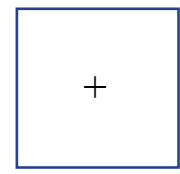

بدون نشانه

مثال هاى شرايط

خنىى

همسو

ناهمسو

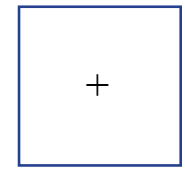

بلون نشانه

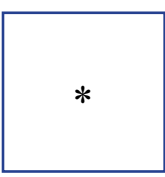

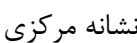

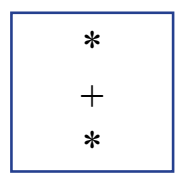

دو نشانه

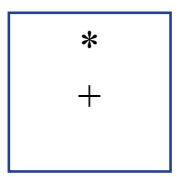

نشانه مكانى

نشانه
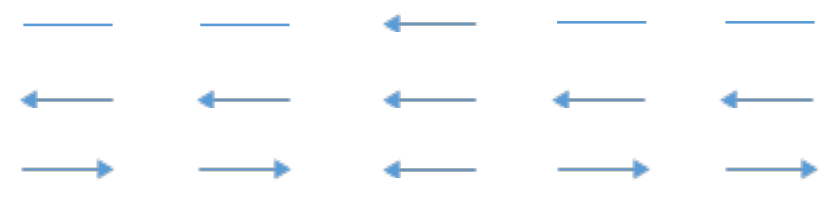

مدل زمانبندى تكليف ANT - مد
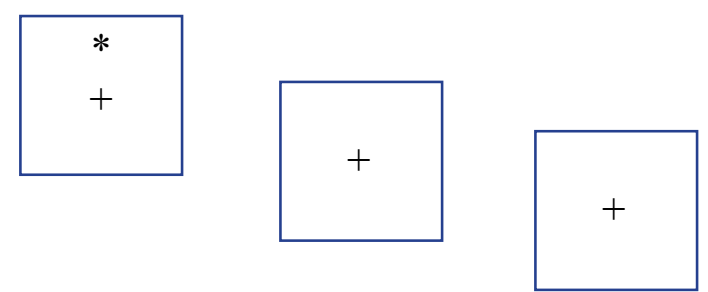

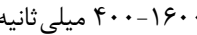

• ( ا ميلمى ثانيه

F. . P

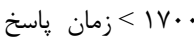

شكل r. شماتيك اجراى (Y) ANT (1)

كه يك هدست كامل است. همجنين از بلوتوث براى انتقال اطلاعات

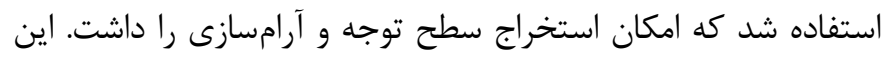

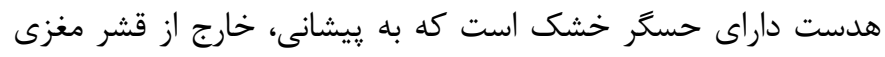
(Cerebral Cortex)

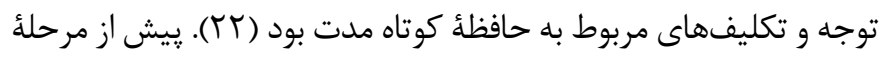
تكليف شبكؤ توجه، از شركت كننده خواسته شد كه هدست امواج مغزى را روى يِيشانى خود نصب كند. سيس آزمون اوليه انجام شد كه آيا ارسال اطلاعات امواج مغزى يا EEG موفقيتآميز است يا خير. اين دستخاه، حسكرى حياتى دارد كه رفتارهاى حياتى الكتريكى را در مغز مىخواند.
تكليف شبكؤ توجه، به معنى تمرين تكليفهاى مرتبط با تناقض، حافظهٔ كارى و ديكر تكليفهاى مرتبط با مكانيزمهاى كنترل اجرايى است. اين تكليفها اغلب براى اجراهاى تكرارى كه شامل كنترلهاى اجرايى است،

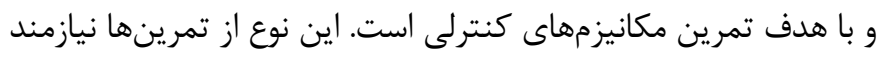
توجه به جهت است و كنترلها براى آموزش شبكههاى مغزى خاص است (T). در جدول ا، مشخصات اين تكليف از منظر افراد داده شده است.

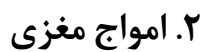
در اين بروهش، همان طور كه قبلا اشاره شد از Neurosky استفاده شد،

جدول 1. مشخصات تكليف ANT

\begin{tabular}{|c|c|}
\hline تعداد & مشخصات تكليف ANT \\
\hline \&T & كل مراحل \\
\hline r & مراحل آزمايشى \\
\hline
\end{tabular}


فرايندى هزينهبر است. در اين :زروهش از روش تحت نظارت استفاده شد، به اين ترتيب كه ابتدا خوشهبندى دستهها با روش خودكار مشخص شد و سيس براى تأييد خوشهها از مقادير خروجى دستگًاه استفاده گرديد. براى ييادهازى الخوريتمهاى يادكيرى ماشين از زبان برنامهنويسى

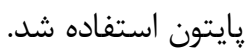

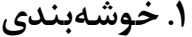

خوشهبندى يكى از شاخههاى يادگيرى بدون نظارت است و فرايند خودكارى است كه در طى آن، نمونهها به دستههايى كه اعضاى آن مشابه يكديگرند تقسيم مىشوند كه به اين دستهها خوشه كفته مىشود. بنابراين خوشه مجموعهاى از نمونهها است كه در آن نمونهها با يكديخر مشابه بوده و با نمونههاى موجود در خوشههاى ديگر غير مشابهاند. براى مشابه بودن مىتوان معيارهاى مختلفى را براى خوشهبندى مورد استفاده قرار داد كه يكى از آنها معيار فاصله است كه در آن مىتوان نمونههايى را كه به يكديگر نزديكترند به عنوان يك خوشه در نظر گرفت. به اين نوع خوشهبندى، خوشهبندي مبتنى بر فاصله نيز كَفته مىشود (TD). هدف خوشهبندى، يافتن خوشههاى مشابه در بين نمونههاى ورودى است، اما انتخاب خوشهبندى مناسب يبيجيده است. با اين حال معيارهاى مختلفى براى مناسب بودن خوشهبندى ارائه شده كه مى تواند كاربر را براى رسيدن به يك خوشهبندى مناسب راهنمايى كند. يكى از مسائل مهرم در خوشهبندى انتخاب تعداد خوشهها است. در روش خوشهبندى، K-means هر داده دقيقأ در يك خوشه قرار مى روش با يارتيشنبندى الگوريتم با K نقطئ اولية تصادفى شروع مىشود و و پس از آن با استفاده از فرايندى تكرارى براى اين كه كيفيت خوشه، به به مراكز جديد بروزرسانى مىشوند. الخوريتم K-means به تعداد خوشههاى مورد نظر، اعداد تصادفى در نظر گرفته مىشود. سيس متناسب با ميزان شباهت، هر يك از نمونهها به يك خوشه تعلق مى گيرد. سيس براى بروزرسانى مراكز، ميانگين دادهاى موجود در هر خوشه، در مركز جديد خوشه قرار داده مىشود. خوشهبندى براى ارزيابى سطح توجه فرد در خوشه مشخص مىشود كه در مدل جايگاه توجه فرد را بازگو مى كند. يس از اين مرحله، برجسبه هاى به دست آمده در دستهبندى از روشهاى يادگيرى ماشين مختلفى استفاده مىشود.

\section{r. نزديكترين K Nمسايكى (KN) (KN)} يكى ديخر از دستهبندى كنندههايى كه در اين يزوهش از آن استفاده شده است، الگوريتمى غير يارامترى است كه نزديكترين K همسايه است. در

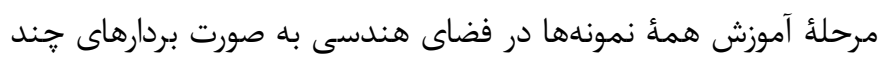

فعاليتهاى مغزى را با استفاده از سه الكترود خشك مى گيرد (مناطق

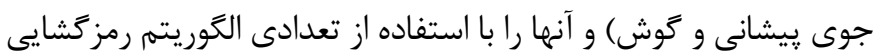
مى كند. اطلاعات دلتا، تتا، آلفا، بتا و كاماى مغزى سطح قدرت باندى كاربر را اندازهخيرى مى كند. جون محلهاى Fp1 و Fp2 در اين هدبند قرار دارد و مو در ريشانى رشد نمى كند، قرارگيرى آن سادهتر است.

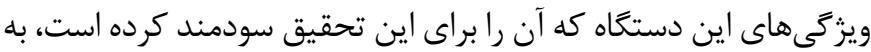

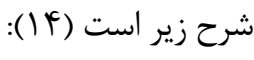

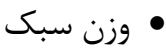

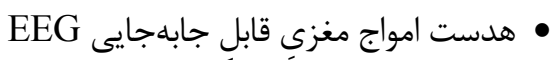

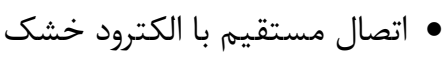

• فيلترهاى بيشرفته با محافظت از نويز زياد اين دستخاه سيخنال هاى خام با باند مغزى در זاه هرتز را جمعآورى مى كند. از تبديل فوريه براى توليد ينج كانال اضافى از موج خام، دلتا، تتا، آلفا و گاما استفاده مى كند (سץ). در اين دستخاه، حدود جههار ثانيه تأخير زمان رسيدن اين مقادير به رايانه وجود دارد و در هر بازه زمانى يك ثانيه مقدار جديد توجه محاسبه ميىشود. مقدار صفر نشاندهنده اين است كه سيخنالى خوانده نشده و مقدار بيش از صفر نشاندهنده افزايش سطح توجه با مقدار نزديك ..1 است (سا). پِس از بررسى اطلاعات، اس داده براى انجام دستهبندى، واجد شرايطِ پردازش اطلاعات است. براى ايجاد ماشينى هوشمند از اطلاعاتِ توجه در سطح عصبى و شناختى از يادكيرى ماشين استفاده كرديم كه براى ايجاد الخوى رفتارى عصبى استفاده شده است (YF).

\section{روند تحليل دادهها}

براى ايجاد مدل، از روشهاى يادگيرى ماشين استفاده شد. اين روش فرايندى كلى دارد و در مرحله (1) ويزگى هاى تأثيرگذار در تعيين كلاسها مشخص مىشود، در مرحلة (r) دادهها جمعآورى مىشوند (در اين مرحله هر يك از ويزگى هاى مرحله قبل براى دادهها محاسبه مىشود). در نهايت در مرحله (ب)، اگر فرايند سيستم تحت نظارت باشد لازم است كه فرد خبرهاى در آن حوزه براى دادهها برجسب كلاس تهيه كند. با اين كار داده آموزش تهيه مىشود. اين داده به دستهبندى كننده مورد نظر داده مىشود و دستابندى كننده مدلى را بر اساس يارامترهاى تنظيمشده ايجاد مى كند. اين مدل نكَهدارى مىشود و سيس دادههاى آزمون، بر اساس دو مرحلة اول ايجاد مىشوند. دادههاى آزمون ورودى با مدل آموزشى و تنظيمى است، سيس مدل مذكور كلاس يا نوع دادهاى آزمون را تعيين مى كند. روش تحت نظارت معمولاً كارايى بهترى نسبت به روش بدون نظارت دارد. البته تعيين برجسب كلاسها 
اين ترتيب عكس مجذور فاصله از رابطةٔ زير محاسبه مىشود:

$$
\|w\|^{2}=\sum_{i, j=1}^{n} \alpha_{i} \alpha_{j} c_{i} c_{j} x_{i}^{T} x_{j}
$$

اهميت هر ويزَّى در مجموعئ داده (هر k يك ويزَى است) يا دست مى آيد، بدين ترتيب كه:

$\|w\|^{2}=\sum_{i, j=1}^{n} \alpha_{i} \alpha_{j} c_{i} c_{j} x_{i}^{T} x_{j}$

اتر مقدار w نزديك به صفر باشد، كارايى دستهبندى كننده بدون وجود اين ويزّى تغييرى نمى كند و اين ويزگى تعيين كننده نيست (TQ).

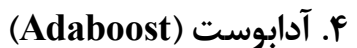

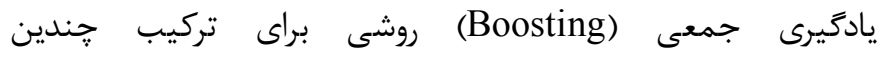
دستهبندى كننده يُايه است كه در واقع مجموعهاى از دستهبندى كنندهها

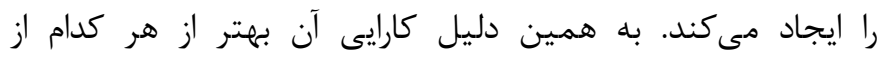

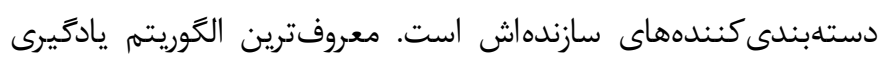

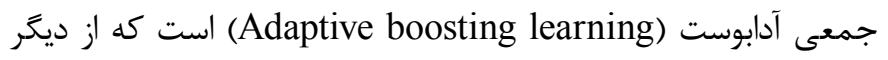

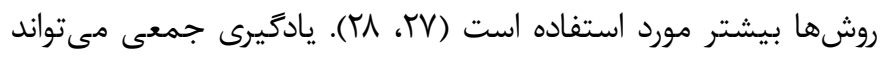

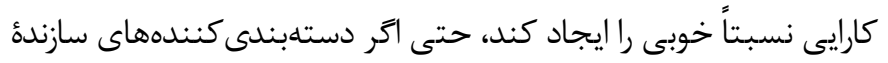

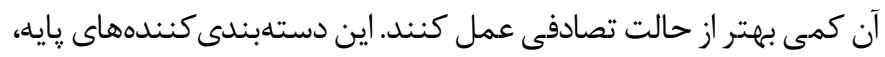
يادكيرندة ضعيف (Weak learner) نيز ناميده مىشوند (9؟). در اين يروهش از درخت تصميمَيرى به عنوان دستهبندى كننده يايه استفاده

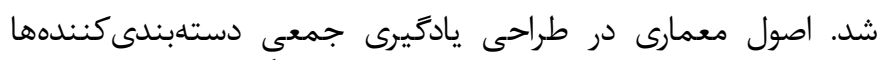

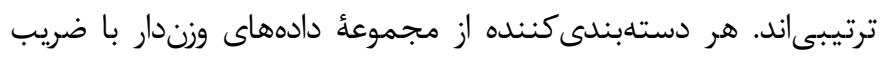

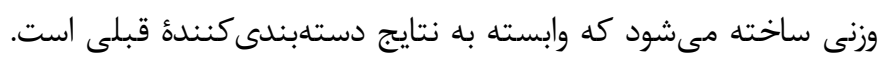

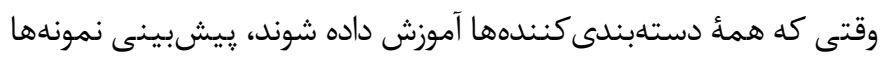

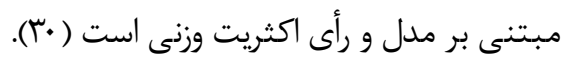

\section{يافته ها}

همانطور كه در جدول r نمايش داده شده است، بعضى از ويزگى ها از طريق دستگاه و يا از طريق تكليف شناختى استخراج شدهاند.

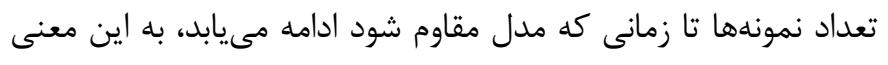

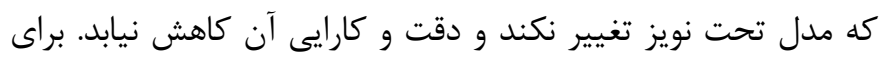

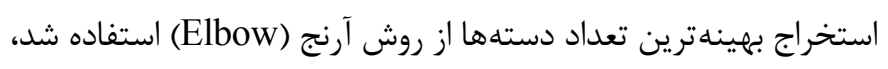

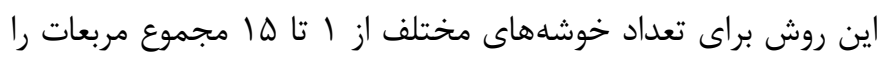

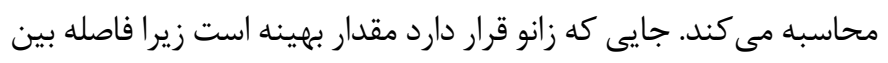

بعدى (هر بردار يكى از ويزگى هاى اندازميرىشده) هستند. اين فضا به برجسبهاى كلاس و موقعيت اين نقاط تفكيك مىشود. معمولاً فاصلة اقليدسى معيار مناسبى است (در اين تحقيق نيز از همين معيار استفاده

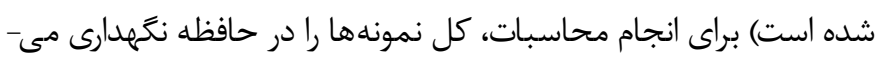

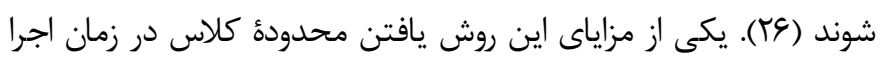

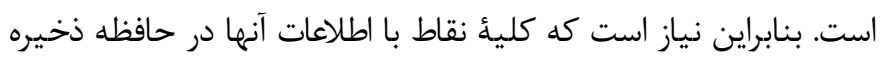

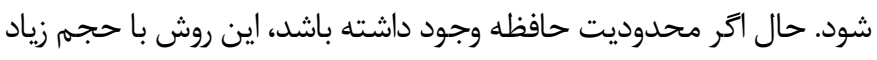

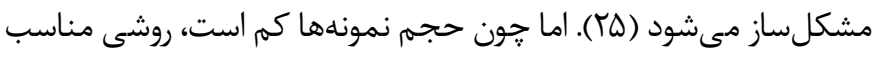
تلقى مىشود.

\section{r. ماشين بردارهاى يشتيبان (SVM)}

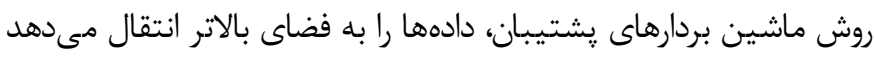

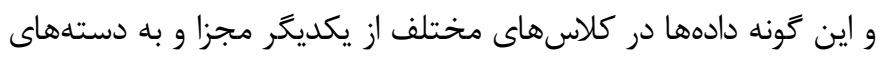

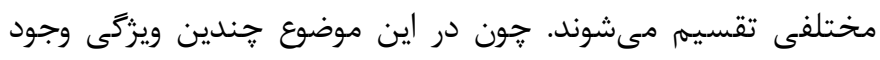

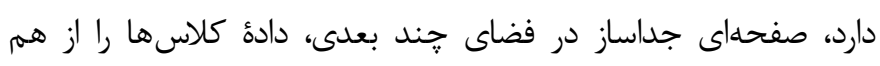

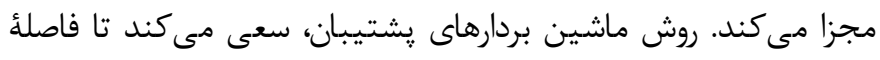

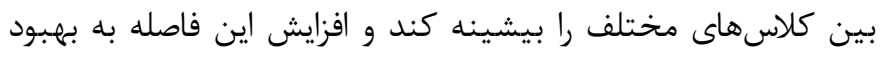
دقت دستهبندى كنندة جداساز منجر مىشود. البته اكر اين فاصله به صورت خطى قابلِ جدا كردن نباشد، با استفاده از هستهُ غيرخطى سعى

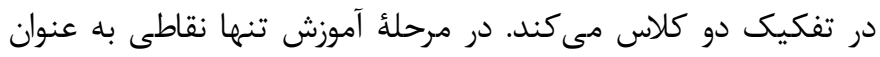

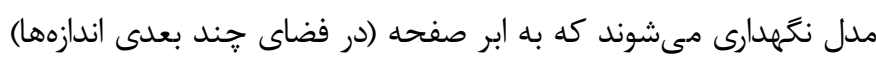

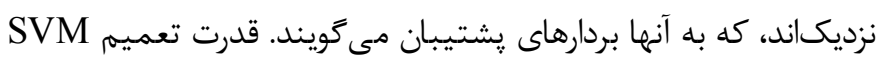

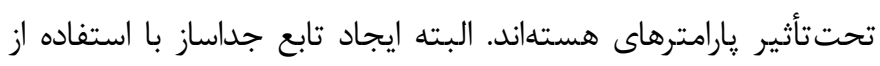

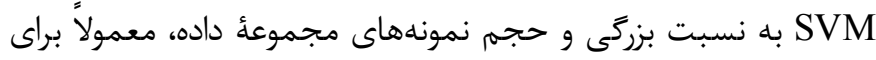

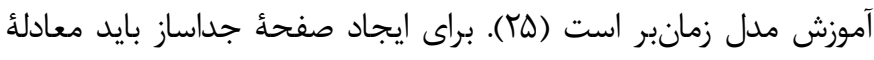

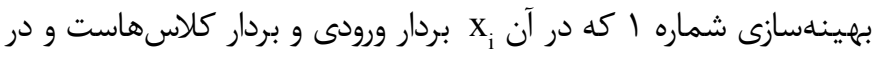

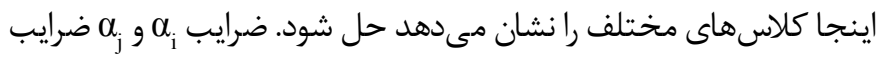

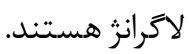

$$
\begin{aligned}
& \sum_{i=1}^{n} \alpha_{i}-\frac{1}{2} \sum_{i, j} \alpha_{i} \alpha_{j} c_{i} c_{i j} x_{i}^{T} x_{j} \\
& \text { and } \sum^{n} \alpha_{i} c_{i}=0 \\
& w=\sum_{i}^{n} \alpha_{i} c_{i} x_{i}
\end{aligned}
$$

اين روش براى انتخاب ويزَگىها نيز استفاده مىشود. دليل ويزَّى

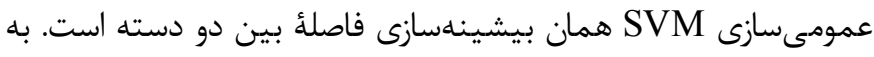




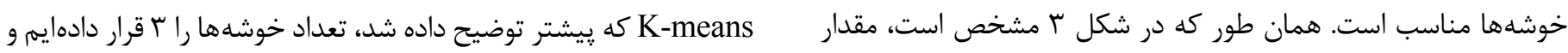

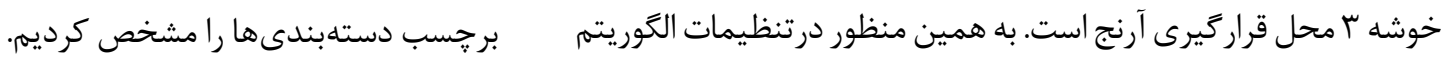

جدول 1. مشخصات تكليف ANT

\begin{tabular}{|c|c|c|c|c|}
\hline 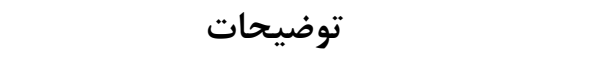 & روش استخراج & 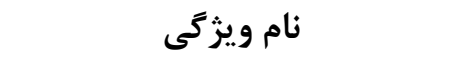 & 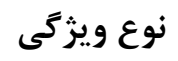 & شماره \\
\hline جريان D/ • - T/VQ هرتز & دستگاه & Stream Power Delta & EEG & 1 \\
\hline 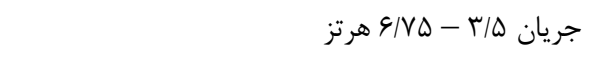 & دستگاه & Stream Power Theta & EEG & $r$ \\
\hline جريان V/D - ج ه هرتز & 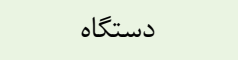 & Stream Power Low Alpha & EEG & $r$ \\
\hline جريان · - 1/VQ الهرتز & دستگاه & Stream Power High Alpha & EEG & p \\
\hline 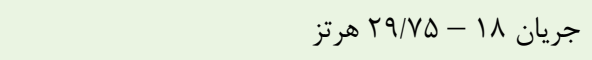 & 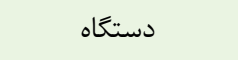 & Stream Power Low Beta & EEG & $\Delta$ \\
\hline جريان 11 - 19 هرتز & دستگاه & Stream Power High Beta & EEG & 4 \\
\hline جريان آ - ج/VQ هرتز & 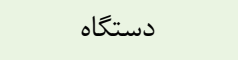 & Stream Power low Gamma & EEG & V \\
\hline 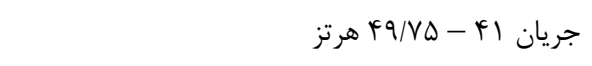 & 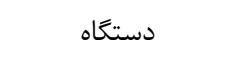 & Stream Power Middle Gamma & EEG & $\Lambda$ \\
\hline 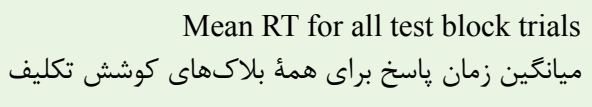 & روانشناختى & mean.all & ANT & 9 \\
\hline $\begin{array}{l}\text { (r) Percent correct over all test trials } \\
\text { درصد صحيح بر همd تكليف كوششها }\end{array}$ & 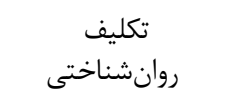 & pc.all & ANT & 1. \\
\hline
\end{tabular}

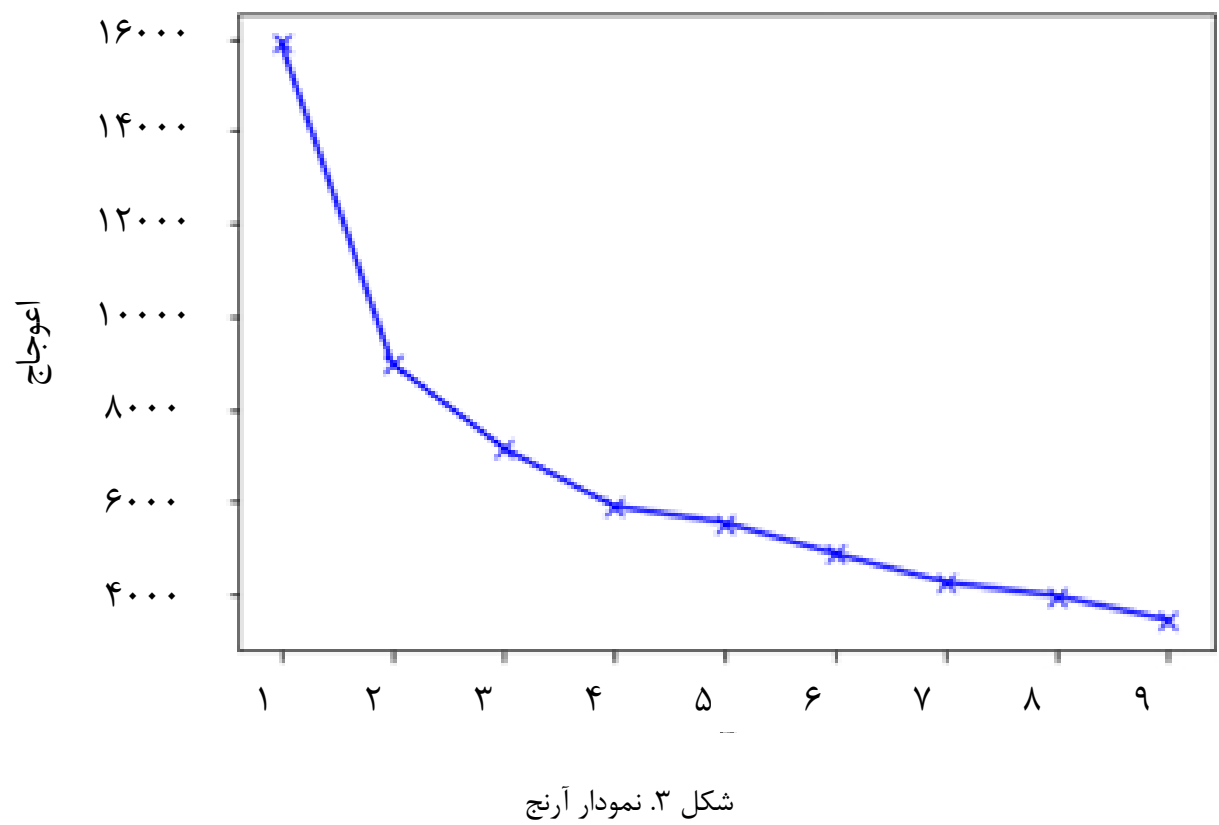


(f) (f)

در اين يزوهش سه مدل يادگيرى ماشين مختلف انجام شده است. جون هدف از اين يزوهش ايجاد مدلى جديد، با روش يادگيرى ماشين براى توجه بود، از روشهاى يادگيرى ماشين: KNN و SVM و Adaboost اطلاعات جمعآورىشده استفاده شد. يكى از جالشهاى اين تحقيق، تعداد نمونهها براى مدلسازى بود و تعداد اين نمونهها كم بود. به همين منظور از روش اعتبارسنجى متقابل (Cross Validation) استفاده شد. يكى از K مبوبترين روشهاى نمونه كيرى مجدد، رويأ اعتبارسنجى متقابل تعداد درختان · ا براى آن مىشود. دستأ K-Fold Cross Validation است كه بسيار ساده و مؤثر و مطمئن است، روشى كه مجموعأ دادهها را به K زير مجموعة مستقل تقسيمبندى مى كند. يكى از اين زير مجموعهها براى يادگيرى دستهبندى كننده انتخاب مىشود، در حالى كه بقيه براى خطاى تعميمسازى استفاده مىشوند (צr)؛

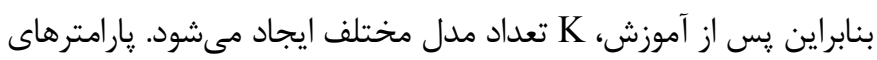
مؤثر در ارزيابى دستهبندى روشهاى ذكرشده در زير آمده است:

جدول r. ارزيابى مدل هاى روشهاى يادگيرى ماشين

نرخ صحيح براى داده آزمون (درصد) پارامترهاى مختلف

بازه نرخ صحيح مدل (درصد)

روش يادگيرى ماشين

\begin{tabular}{|c|c|c|c|}
\hline تابع خطى & 94 & $9 F(-1+\cdot / 1 T)$ & SVM \\
\hline $\mathrm{K}=\mathrm{r}$ & $1 \cdots$ & $9 \vee(-/+\cdot / 1 \%)$ & KNN \\
\hline تعداد درختان · & 4. & $\Lambda \Lambda(-I+\cdot / Y T)$ & Adaboost \\
\hline
\end{tabular}

طولانى به طور منظم ترمز نمى كنند، خطر بالاى خواب آلودگى دارند. در تحقيقات قبلى تاكيد بر ايجاد مدل هوشمند، تحليل تصاوير حالت جشم يادگيرى ماشين حركات خواب است (اس). يك روش ديگر، استفاده از مدل هوشمند امواج مغزى براى تشخيص عدم توجه است كه در اين مقاله ايجاد شده است. يكى ديخر از كاربردهاى اين يزوهش، هوشمندسازى ماشين ها و يا ربات ها مى باشد.

\section{نتيجه كَيرى}

با توجه به دادههاى جمعآورى شده، مدل يادگيرى ماشين KNN انتخاب شد. اين روش براى نمونههاى كم مناسبتر است. در صورتى كه دادههاى آزمايش بيشتر شود، مدلهاى مقاومترى ايجاد مى شود كه كارايى بيشترى نيز دارند. روشهاى يادگيرى ماشين امكان دستهبندى نمونهها را دارند و در مطالعات شناختى بسيار كارآمد هستند. در آينده از اين مدل ها براى تعامل انسان و ماشين ها بسيار استفاده خواهد شد.
استفاده از اين دستگاه BCI براى تحقيق در زندگى روزمره انجام شود. اين دستخاهها جون ارزانترند و قابليت جابهجايى دارند، براى استفاده از مناطق باز مناسباند و مىتوان تكليفهايى را در حين رانندگى يا كارهاى ديخرى كه به توجه زياد نياز دارند مورد استفاده قرار داد (آ). اما محدوديت اين ابزار در دقت كمتر آن نسبت به دستخاههاى يزشكى EEG يكى از اصلىترين جالشهاى اين يزوهش همان طور كه يِيش از آن كفته شد جمع آورى اطلاعات از افراد بيشترى است و بنابراين انتخاب الخوريتم Adaboost افراد ناتوان حركتى يكى ديگر از كاربردهاى جنين مدلهايى است (זr). روش KNN نسبت به بقية روشها از دقت بيشترى برخوردار است. اين مدل يادگيرى ماشين براى ييشبينى سطح هشدار توجه مخصوصاً براى يادگيرى و تعامل با رايانه مى تواند استفاده شود، همجنين يكى ديگر از كاربردهاى اين تحقيق براى رانندگانى است كه در طى زمانى 
شركت كردند، همجنين از موسسه آموزش عالى علوم شناختى و گروه مدل سازى براى راهبرى اين يزوهش، كمال تقدير و تشكر را داريم.

\section{References}

1. Ong G, Sewell DK, Weekes B, McKague M, Abutalebi J. A diffusion model approach to analysing the bilingual advantage for the Flanker task: The role of attentional control processes. Journal of Neurolinguistics. 2017;43(Part A):28-38.

2. Bourgeois A, Neveu R, Bayle DJ, Vuilleumier P. How does reward compete with goal-directed and stimulus-driven shifts of attention?. Cognition and Emotion. 2017;31(1):109-118.

3. Quinn K. An in depth study of how the psychological behaviors affect construction safety [MSc Thesis]. West Lafayette, Indiana:Purdue University;2010.

4. Khasraghi BJ, Setayeshi S. Applying fuzzy mathematical model of emotional learning for eeg signal classification between schizophrenics and control participant. International Journal of Neural Systems. 2017;4(1):49-54.

5. Posner MI, Petersen SE. The attention system of the human brain. Annual Review of Neuroscience. 1990;13(1):25-42.

6. Tychkov AY, Alimuradov AK, Ageykin AV, Tychkova AN. Multi-neural interface of borderline mental disorders express-evaluation. International Journal of Applied Engineering Research. 2017;12(16):6224-6229.

7. Yildirim N, Varol A. Developing educational game software which measures attention and meditation with brainwaves: Matching mind math. In ICEE/ICIT Conference. 2013 Dec 8-12; Cape Town, South Africa;2013.

8. Rebolledo-Mendez G, Dunwell I, Martínez-Miron EA, Vargas-Cerdán MD, De Freitas S, Liarokapis F, et al. Assessing neurosky's usability to detect attention levels in an assessment exercise. In International Conference on Human-Computer Interaction; 2009 Jul 19; Springer, Berlin, Heidelberg. pp. 149-158. 9. Jafri SR, Hamid T, Mahmood R, Alam MA, Rafi T, Haque
MZ, et al. Wireless brain computer interface for smart home and medical system. Wireless Personal Communications. 2019;106(4):2163-2177.

10. Li M, Liang Z, He B, Zhao CG, Yao W, Xu G, et al. Attention-controlled assistive wrist rehabilitation using a low-cost EEG Sensor. IEEE Sensors Journal. 2019;19(15):6497-6507. 11. Folgieri R, Lucchiari C, Marini D. Analysis of brain activity and response to colour stimuli during learning tasks: an EEG study. In Color Imaging XVIII: Displaying, Processing, Hardcopy, and Applications. 2013 Feb 4-6; Burlingame, Ca, United States; Washington:International Society for Optics and Photonics;2013. Vol. 8652, p. 86520I.

12. Jones A, Schwartz G. Using brain-computer interfaces to analyze EEG data for safety improvement. Berkeley, CA:Team for Research in Ubiquitous Secure Technology;2010.

13. Rebolledo-Mendez G, De Freitas S. Attention modeling using inputs from a Brain Computer Interface and user-generated data in second life. In ACM Tenth International Conference on Multimodal Interfaces (ICMI). 2008 Oct 20-22; Chania, Crete, Greece;2008.

14. Tiwari K, Saini S. Brain controlled robot using neurosky mindwave. Journal of Technology Advances Scientific Research. 2015;1(4):328-331.

15. Bose J, Singhai A, Patankar AA, Kumar A. Attention sensitive web browsing. In Proceedings of the 9th annual ACM India conference. 2016 October 21-23; Gandhinagar, India. pp. 147-152.

16. Peters C, Asteriadis S, Rebolledo-Mendez G. Modelling user attention for human-agent interaction. In 10th Workshop on Image Analysis for Multimedia Interactive Services. 2009 May 6-8; London, United Kingdom; New Jersey:IEEE;2009. 
pp. 266-269.

15. Bose J, Singhai A, Patankar AA, Kumar A. Attention sensitive web browsing. In Proceedings of the 9th annual ACM India conference. 2016 Oct 21-23; Gandhinagar, India. pp. $147-152$.

16. Peters C, Asteriadis S, Rebolledo-Mendez G. Modelling user attention for human-agent interaction. In 10th Workshop on Image Analysis for Multimedia Interactive Services. 2009 May 6-8; London, United Kingdom; New Jersey:IEEE;2009. pp. 266-269.

17. Hondrou C, Caridakis G. Affective, natural interaction using EEG: Sensors, application and future directions. In Hellenic Conference on Artificial Intelligence; 2012 May 28; Berlin, Heidelberg, Germany; Springer;2012.

18. Ghanbari AA, Heidari E, Setayeshi S. Brain emotional learning based Brain Computer Interface. International Journal of Computer Science Issues (IJCSI). 2012;9(5):146-154.

19. Lovibond PF, Lovibond SH. The structure of negative emotional states: Comparison of the Depression Anxiety Stress Scales (DASS) with the Beck Depression and Anxiety Inventories. Behaviour Research and Therapy. 1995;33(3):335-343. 20. Dye MW, Green CS, Bavelier D. The development of attention skills in action video game players. Neuropsychologia. 2009;47(8-9):1780-1789.

21. Tang YY, Posner MI. Attention training and attention state training. Trends in Cognitive Sciences. 2009;13(5):222-227.

22. Liarokapis F, Vourvopoulos A, Ene A, Petridis P. Assessing brain-computer interfaces for controlling serious games. In 2013 5th International Conference on Games and Virtual Worlds for Serious Applications (VS-GAMES). 2013 Sep 1113; Poole, United Kingdom;2013. pp. 1-4.
23. Xu Y, Chang KM, Yuan Y, Mostow J. EEG Helps Knowledge Tracing!. In Intelligent Tutoring Systems (ITS 2014 WSEEG). 2014 Jun 5-9; Hawaii, United States;2014. p. 43.

24. Webb GI, Pazzani MJ, Billsus D. Machine learning for user modeling. User Modeling and User-Adapted Interaction. 2001;11(1-2):19-29.

25. Alpaydin E. Introduction to machine learning. Cambridge:MIT Press;2014;22

26. Burkov A. The Hundred-Page Machine Learning Book. Quebec City, Can:Andriy Burkov;2019.

27. Haque MN, Moscato P. From ensemble learning to meta-analytics: A review on trends in business applications. In: Moscato P, De Vries N, editors. Business and consumer analytics: New ideas. Cham, Switzerland:Springer;2019. pp. 703-731.

28. Taşcı E. A meta-ensemble classifier approach: Random rotation forest. Balkan Journal of Electrical and Computer Engineering. 2019;7(2):182-187.

29. Panesar A. Machine learning and ai for healthcare. New York:Apress;2019.

30. Geron, A. Hands-On machine learning with scikit-learn, keras, and tensorflow: concepts, tools, and techniques to build intelligent systems. 2nd ed. Sebastopol, CA:O’Reilly Media;2019. 31. Saini V, Saini R. Driver drowsiness detection system and techniques: A review. International Journal of Computer Science and Information Technologies. 2014;5(3):4245-4249.

32. Serna B, Baltazar R, Casillas M, Saavedra Y, Alanis A, Meza A. Medical diagnostic through a mobile application controlled by brain waves: Consult app. In: Jezic G, Chen-Burger YH, Kusek M, Šperka R, Howlett R, Jain L, editors. Agents and multi-agent systems: Technologies and applications 2019. Singapore:Springer;2020. pp. 185-193. 